\title{
Can Social Characteristics Confine the Use of Airbnb Platform? A Case Study of Aswan and Wahat in Egypt
}

\author{
By Mohamed Hany B. Moussa*, Sameh Gamal Saad ${ }^{ \pm}$\& \\ Catherine Goerge Messeha ${ }^{+}$
}

\begin{abstract}
Airbnb became the largest share economy platform in the world with an expected 500 million guests deriving 3 billion dollars profits in 2020. In many destinations, the Airbnb platform provides the umbrella for private dwellings owners to participate in the global tourism movement. Aswan and Wahat are two Egyptian destinations where private dwellings are in use in isolation from this platform as well as any governmental cover despite their existence. Neither the Ministry of Tourism "MoT" nor the Egyptian Tourism Federation "E.T.F" provide any umbrella for this activity despite its existence and popularity. PESTEL is a model that is geared toward exploring the adequacy of destinations for projects. This paper uses this model to find out the impact of social and demographic elements of the model to differentiate between destinations about their adequacy to adopt the Airbnb platform. Findings indicate that local, social and demographic disputes may make the difference in adequacy, albeit all other PESTEL factors conformity.
\end{abstract}

Keywords: private dwellings, Airbnb platform, social and demographic characteristics, PESTEL

\section{Background}

Airbnb is considered a trustworthy website for those who want unique accommodation to list, explore, and book around the world (Airbnb 2016). It is an online platform where common people rent their premises for visitors. Usually, such rooms include a whole house (for example an apartment or home) or a private space in a residence that also includes the host. Therefore, a very limited percentage of Airbnb's listings are shared rooms (for example, a guest can sleep in the living room on a futon). The numerous inventories of Airbnb often range from very modest to highly luxurious. Nevertheless, in the 2012 Companies factsheet, $57 \%$ of their lists were entire homes, $41 \%$ private and $2 \%$ shared spaces (Airbnb 2012). Airbnb does not include a precise breakdown. This general overview has been supported by a more recent independent data review taken from the Airbnb website.

Tom Slee (2013) noticed that 56\% of the New York City listings about Airbnb were the entire household, with two-thirds of the listing of Airbnb in New York City with at least one comment being whole residences. In February 2016, data from the Airbnb website for 32 major global cities showed that on average $64 \%$ of

\footnotetext{
*Professor, Hospitality Management Department, FTH, Helwan University, Egypt.

${ }^{ \pm}$Associate Professor, Hospitality Management Department, FTH, Helwan University, Egypt.

${ }^{+}$Researcher/Ex-Demonstrator, Hurghda Higher Institute for Hospitality Management, Egypt.
} 
the cities listed by Airbnb were for whole houses, $34 \%$ for private rooms, and $2 \%$ for shared premises. Airbnb operators (i.e., "hosts") lease one or more Airbnb lists as permanent short-term rentals, a second house, or even one or more Airbnb lists. Approximately $90 \%$ of Airbnb hosts are renting their primary house (Airbnb 2016), but hosting (apparently "professional") hosting is a proportionately greater share of Airbnb's overall listings and reservations (Clampet 2014, Schneiderman 2014, Tom Slee 2014, Coldwell 2016, O’Neill and Ouyang 2016, Popper 2015).

Airbnb has recently been trying to attract business travelers who only represent a small part of Airbnb visitors, create a dedicated travel platform with custom search results and expense management instruments, partner with several corporate travel companies, and launch a "Business Travel Ready" badge, which can be obtained via listings that have certain characteristics. Little information on user demographics is available, but Airbnb reported that in 2012 for example some $40 \%$ of its guests were from the US, with the remainder of Europeans comprising the majority of the rest (Taylor 2012). Just over the half was in Europe at the time, and just over a quarter was in North America (Taylor 2012), with more than half of the entries in Europe only confirmed at the start of 2015 (Shead 2015). A summer-in 2015 study by Airbnb also found that its average visitors' age was 35 (Airbnb 2015) and the average visitor age was 14 to 36 (Williams 2014) and that during the summer 2015 survey, 54\% of the guests were female (Airbnb 2015).

\section{Why Tourists Choose Airbnb}

A handful of studies have begun the process of understanding why tourists choose Airbnb. To begin with, Lamb (2011) used phenomenological life-world interviews to examine the motivations behind Couch Surfing and Airbnb hosts and guests, focusing on their desire for authentic interpersonal experiences. He found that Airbnb guests were primarily attracted to the service by their desire for such experiences, but Lamb also noted financial savings played a small role in their decisions. Lamb's predetermined focus on authentic interpersonal experiences permitted a rich examination of that topic, but it also prevented a more comprehensive assessment of the motivations behind Airbnb use. Also, Lamb's study devoted comparatively more attention to Couch Surfing than to Airbnb, and only involved a handful of interviews with Airbnb guests. Guttentag (2015) examined Airbnb through the conceptual lens of disruptive innovation, and he proposed three key appeals of Airbnb based on a review of the relevant academic and media literature, i.e., price, household amenities, and authenticity. However, Guttentag's paper is conceptual rather than empirical, so no data beyond a cost comparison of Airbnb and hotels are offered to support the three motivating factors he proposes. Tussyadiah (2015) surveyed users focusing on motivations drawn from the collaborative consumption literature. An exploratory factor analysis grouped these motivations into three factors that are; Sustainability, Community, and Economic Benefits. She found that all three factors had an influence, with economic Benefits being the most significant. However, Tussyadiah's grounding in the collaborative consumption literature may have restricted 
the scope of her analysis, as she devoted significant attention to matters of sustainability but failed to consider practical motivations beyond cost or to explicitly consider authenticity (which she found some respondents mentioned in an open-ended item). However, Tussyadiah only surveyed U.S. users in general, instead of just Airbnb. Because some major PSR companies offer primarily second homes that are located in traditional vacation rental markets, these services' appeal may be distinct from Airbnb's. In a somewhat similar study, Tussyadiah and Pesonen (2015) examined motivations of use among American and Finnish users. The authors used 12 motivation statements rooted in the collaborative consumption literature, and exploratory factor analysis revealed two factors that are: social Appeal and economic Appeal - plus several items (including location convenience and search efficiency) that did not load onto either factor. However, the authors did not indicate the strength of agreement with the different motivational factors but rather used the factor scores as independent variables in a multiple regression looking at how the use impacts different travel decisions. Also, this study exhibits some of the same limitations as the Tussyadiah (2015) study, namely that practical benefits were not broadly considered, authenticity was not explicitly included, and the respondents were users of any PSR service. Quinby and Gasdia (2014), surveyed users and found the top three reasons they chose were home-like amenities, more space, and better value, in the same order they are mentioned (Hennessey 2014). However, like the studies of Tussyadiah (2015) and Tussyadiah and Pesonen (2015), Quinby and Gasdia (2014) looked at PSRs in general instead of Airbnb specifically. Nowak et al. (2015), working for Morgan Stanley, surveyed U.S. and European travelers to gauge Airbnb's potential threat to hotels and online travel agencies. The respondents who used Airbnb within the previous year were asked about the factors that led them to do so. 55\% indicated "cheaper price", 35\% indicated "location", 31\% indicated "authentic experience", $25 \%$ indicated "own kitchen", 24\% indicated "uniqueness of unit", 23\% indicated "easy to use app/site" and 17\% indicated "large party accommodation". However, this study examined total Airbnb use instead of the choice to use Airbnb on a specific trip, which may have complicated the findings because one's reasons to use Airbnb may vary between different trips (e.g., a leisure trip versus a business trip). Finally, Airbnb has produced economic impact reports focusing on about two dozen different major worldwide destinations, and these reports provide occasional insights into why guests choose Airbnb. Numerous reports have indicated that roughly $90 \%$ of Airbnb guests were looking to "live like a local" (Airbnb 2013, 2014, 2015, 2016), a couple of reports stated that roughly $80 \%$ of Airbnb guests used it because the location was more convenient than that of a comparable hotel (Airbnb 2014, 2015), and several reports claimed that about 80 to $90 \%$ of Airbnb guests chose it for the amenities (Airbnb 2015). However, in addition to potential biases with research commissioned by Airbnb, it is difficult to interpret patterns between the reports because they are not perfectly consistent in the variables covered, making it unclear if some findings are being excluded from some reports. 


\section{Proposed Motivations to Use Airbnb according to Innovation Concepts}

The disruptive innovation and diffusion of innovations literature do not provide a precise framework for understanding the motivations that attract guests to Airbnb, but in combination with the existing Airbnb and tourism accommodation choice literature, the two innovation concepts still provide a very useful lens through which to recognize and understand these motivations. Based on this combined literature, potential motivations to use Airbnb were proposed as relating to six different dimensions - price, functional attributes, unique and local authenticity, novelty, bragging rights, and sharing economy ethos.

Price

As previously described, low cost is a classic characteristic and appeal of disruptive innovations (Christensen 1997), and Adner's (2002) analysis of consumer demand for disruptive innovations stressed the critical importance of price. Likewise, innovation diffusion research recognizes that financial cost is a very common aspect of relative advantage; indeed, economic factors are the very first variety of relative advantage that Rogers (2003) described. As was also previously discussed, in their studies of Airbnb and PSR users, Tussyadiah (2015) and Nowak et al. (2015) both found financial savings were the principal reason guests use Airbnb and PSRs, and Guttentag (2015) and Lamb (2011) also both recognized the importance of this appeal. The attraction of Airbnb's low cost also has been highlighted in countless media stories on the company (Ennion 2013, Harwell 2014, Pilon 2014, Rosenberg 2014, Schoettle 2015). As was also mentioned, the price has additionally been identified as a key factor in hotel choice (Chu and Choi 2000, Dolnicar and Otter 2003). Moreover, based on their previous research on Zipcar, they argued that the sharing economy is driven primarily by a desire for cost savings and convenience, also, Hamari et al. (2015) similarly found that economic benefits were a significant motivator for intention to use the sharing economy services. Numerous analyses have indicated that Airbnb accommodations tend to be inexpensive in comparison with hotels, even though they may be more expensive than hostels (Busbud.com 2016, Guttentag 2015, Haywood et al. 2016, Hockenson 2013). However, some recent research somewhat surprisingly disputes the common notion that Airbnb generally offers significant cost savings.

\section{Functional Attributes}

As earlier discussed, the disruptive innovation literature takes the perspective of Lancaster (1966) that products can be viewed as the sum of their various attributes (Christensen 1997, Adner 2002). In practice, such attributes (aside from price) have almost exclusively been functional ones; for example, the concept of disruptive innovation originated in research on computer disk drives for which the primary attributes were size and storage capacity (Bower and Christensen 1995). Tussyadiah and Zach (2015) found the location was important for both hotels and 
PSRs, even though hotel guest reviews tended to focus on a location's convenience and PSR reviews tended to focus on a location's more general desirability.

\section{Unique and Local Authenticity}

The appeal of a more "homely" atmosphere emphasizes the importance of looking beyond strictly tangible attributes to additionally consider the experiential aspects of an Airbnb stay. Ahuvia and Izberk-Bilgin (2011) built on this idea by suggesting that this discontent is inspiring a consumer embrace of "e-Bayization". This countertrend to McDonaldization describes how information technology is transforming consumer society by permitting especially high levels of variety, unpredictability, and market-mediated control (e.g., online reputational systems). These three characteristics perfectly encapsulate Airbnb, and one of Airbnb's cofounders has even likened the company to eBay (Buhr 2014). Other authors have used different terminology to describe this same general trend. Gilmore and Pine (2011) stated that a process of commoditization has expanded from goods to services, meaning many competing service brands are virtually indistinguishable and compete primarily on price. The authors argued that customers seek memorable experiences via the emerging "experience economy", and are therefore increasingly unwilling to accept such standardization for reduced costs. The facilitation of authentic local experiences is also sometimes mentioned in guidebook references to Airbnb (St. Louis 2012, Williams et al. 2015), and is frequently stated in media stories about the company (Cadwalladr 2013, Capellaro 2013, Bradbury 2014, Vaccaro 2014, Weisleder 2014). As was described before, the importance of authenticity and interpersonal experiences as a motivation for Airbnb stays has also been noted by Lamb (2011), Guttentag (2015), and Tussyadiah (2015).

\section{Novelty}

The previously discussed concept of personal innovativeness (one's tendency to adopt innovations more quickly or slowly than others) (Rogers 2003), which is a major topic within the diffusion of innovations, is very closely related to the notion of novelty-seeking. Likewise, Khare et al. (2010) viewed the two constructs jointly in a study of online shopping behavior among Indian youth. Noveltyseeking also has been used by numerous other tourism scholars to better understand tourist choices and behavior. For example, Snepenger (1987) segmented the Alaskan vacation market using novelty-seeking roles rooted in Cohen's (1972) work; Chang et al. (2006) segmented visitors to Taiwanese aboriginal attractions based on novelty-seeking motivations; Jang and Feng (2007) found noveltyseeking was positively associated with mid-term revisit intentions among international French tourists; and Aaker (2011) found novelty-seeking among European travelers was associated with lower immediate revisit intentions but higher long-term revisit intentions. As an innovative form of tourism accommodation, it seems natural to consider the novelty of Airbnb as a motivation influencing Airbnb choice. Firstly, novelty seekers could be drawn to Airbnb 
simply because it is a novel form of tourism accommodation. Secondly, as related to the broader experience that Airbnb provides, Airbnb accommodations could be perceived as facilitating a more novel overall travel experience than could be had in a traditional form of accommodation.

\section{Bragging Rights}

Rogers (2003) highlighted that social prestige is often a key component of the relative advantage that innovation can offer. Indeed, Rogers noted that over a century ago, Gabriel Tarde, one of the originators of diffusion thinking, identified status-seeking as the main reason for people to imitate the innovative behaviors of others. Travel bragging and social status have also been considered as a motivating factor in Cha et al. (1995) study segmenting Japanese overseas travelers; Sirakaya et al.'s (2003) study segmenting Japanese travelers to Turkey; Kim and Prideaux's (2005) study on the travel motivations of visitors to Korea; Kim et al.'s (2007) study on the travel motivations of U.S. university students; and Lee et al. (2002) study on the travel motivations of German international tourists. Although the tourism research on bragging rights and social status has focused chiefly on general travel motivations, the diffusion of innovations literature demonstrates that this concept is relevant and possibly important to understanding the adoption of specific tourism product innovations like Airbnb.

\section{Sharing Economy Ethos}

When considering the diffusion concept of compatibility, which highlights an adopter's values and beliefs (Rogers 2003), it seems important to recognize the values of the broader sharing economy in which Airbnb resides. Key values in the sharing economy include sustainability, local consumption, and trust between strangers (Botsman and Rogers 2010, Chase 2015, Gansky 2010, Pricewaterhouse Cooper 2015). Airbnb fully endorses such values, as illustrated by its economic impact reports that often feature sections related to both environmental and social benefits. Furthermore, as was previously summarized, studies by Tussyadiah (2015) and Tussyadiah and Pesonen (2015) found that motivations directly relating to the sharing economy play an important role in influencing PSR use. These studies included fairly similar items covering motivations such as supporting residents, reducing resource consumption, and preferring Airbnb's sustainable business model, which loaded onto factors termed "Sustainability" (Tussyadiah 2015) and "Social appeal" (Tussyadiah and Pesonen 2015).

\section{Negative Sides of Airbnb Alternative Accommodations}

A recent study explored sources of distrust in the Airbnb. The study focused on Airbnb customers' negative reviews posted in English on Trustpilot's website. Two main findings were found. i.e., poor customer service and host unpleasant 
behavior. Eventually, the study called for more care on service and a higher trustbased relationship between host and guests.

Customers of the sharing economy - like, Airbnb - are exposed to other risks than monetary loss (Ert et al. 2016), and guests may be confronted with unreliable hosts or even personal security (Huurne et al. 2017). In most cases, the host rents rooms to strangers (Ert et al. 2016), and the host competence defines the accommodation service quality (Zhang et al. 2017). As a result, many unexpected incidents may occur, as guests cannot determine one another's reliability in advance (Sun et al. 2019). For instance, a recent unfortunate incident involved the sexual assault of a nineteen-year-old boy by his Airbnb host during his stay in Madrid (Lieber 2015). Although the notion of sharing assumes trust between the two parties, host and guest (Lee et al. 2015, Parigi and Cook 2015), such unpleasant experiences may certainly occur, and eventually causes distrust, and might discourage travelers from staying at Airbnb accommodations (So et al. 2018). Recent studies identified distrust as one of the major barriers surrounding consumers' use of Airbnb (Tussyadiah and Pesonen 2018) and, in some cases, the only constraint that significantly predicts the overall consumer attitude towards Airbnb (So et al. 2018).

Aside from monetary risks, additional risks do also exit in sharing economy platforms like Airbnb Ert et al. (2016). The authors stress that "the mere act of sharing a home with a stranger can be risky" (Ert et al. 2016). Such risks and unpleasant experiences may lead to distrust and discourage travelers from choosing Airbnb as an alternative to conventional accommodation types (So et al. 2018). From another perspective, since Airbnb is a third-party platform that offers online accommodation services between sellers and buyers, the risk is always there. However, Airbnb consumers have one choice but to estimate the risk of their transactions from the available information and communications because they cannot experience the actual service before they arrive at their chosen properties (Liang et al. 2018). In the same context, most P2P accommodation platforms are suffering flimsy trust (Ert et al. 2016, Wu et al. 2017). Recent studies indicate that distrust is the most frequently cited barrier to $\mathrm{P} 2 \mathrm{P}$ accommodation in a sharing economy, which includes the basic mistrust among strangers and privacy concerns (So et al. 2018, Tussyadiah and Pesonen 2018).

\section{Poor Customer Service from Airbnb}

In a recent study, of the two hundred and sixteen negative reviews posted, $89.81 \%$ were associated with poor customer service experiences that caused distrust in Airbnb. Notions on poor customer service included: "there is no phone/ email support", "simply ignored", "can't get any help from Airbnb", "contact with this organization is virtually impossible", "Airbnb failed to help us in any useful way", "Airbnb made no effort to make things right for me", "can't refund the money", "customer service is a nightmare", "wait for a response...usually weeks", "I no longer can place any trust in...even their customer service", "Airbnb...they do not care", "customer service team just doesn't exist", "no one from Airbnb contacted me", "was not resolved until 26 hours after my initial submission", "just 
denied that was their problem", "Airbnb will not help you", "dismissed my claims", "worst customer service", "bad customer service", and "customer service is poor". I would not use Airbnb or recommend Airbnb to anyone else.

On experiencing a service quality failure, customers usually complain to service providers to alleviate their stress and get protection. In this background, many Airbnb guests contacted the company's customer service department; however, Airbnb's gave inadequate responses and poor interactions, this designated a low level of benevolence from the customer service staff towards their customers, in turn, this caused high levels of ambivalence and uncertainty among customers that were expressed in psychological distress (Moody et al. 2017). As a result, guests' distrust in Airbnb was amplified, to the point that some customers noted they would stop using the service. This decision can be linked to institution-based reasons; in other words, these guests practiced what they considered as an unsatisfactory reaction and referred to weak regulations.

\section{PESTEL Outcomes Effects on Project Performance}

The PESTEL Analysis is used as a tool of situational analysis for business evaluation purposes and is one of the most used models in the evaluation of the external business environment that is highly dynamic (Perera 2017).

PESTEL model is one of the most recent models that are used to evaluate the adequacy of a locality, a destination, or a country to accommodate new projects. It has six dimensions as explained in the next section.

\section{Political Factors}

These factors are all about how and to what degree a government intervenes in the economy or a certain industry. All the influences that a government has on your business could be classified here. This can include government policy, political stability or instability, corruption, foreign trade policy, tax policy, labor law, environmental law, and trade restrictions. Furthermore, the government may have a profound impact on a nation's education system, infrastructure, and health regulations. These are all factors that need to be taken into account when assessing the attractiveness of a potential market.

\section{Economic Factors}

Economic factors are determinants of a certain economy's performance. Factors include economic growth, exchange rates, inflation rates, interest rates, disposable income of consumers, and unemployment rates. These factors may have a direct or indirect long term impact on a company since it affects the purchasing power of consumers and could change demand/supply models in the economy. Consequently, it also affects the way companies, price their products and services. 


\section{Social Factors}

This dimension of the general environment represents the demographic characteristics, norms, customs, and values of the population within which the organization operates. This includes population trends such as the population growth rate, age distribution, income distribution, career attitudes, safety emphasis, health consciousness, lifestyle attitudes, and cultural barriers. These factors are especially important for marketers when targeting certain customers. Besides, it also says something about the local workforce and its willingness to work under certain conditions. In some cases, social factors are divided into social and demographic factors to be more precise and conclusive.

\section{Technological Factors}

These factors pertain to innovations in technology that may affect the operations of the industry and the market favorably or unfavorably. This refers to technology incentives, the level of innovation, automation, research, and development (R\&D) activity, technological change, and the amount of technological awareness that a market possesses. These factors may influence decisions to enter or not enter certain industries, to launch or not launch certain products, or to outsource production activities abroad. By knowing what is going on technologywise, you may be able to prevent your company from spending a lot of money on developing a technology that would become obsolete very soon due to disruptive technological changes elsewhere.

\section{Environmental Factors}

Environmental factors have come to the forefront only relatively recently. They have become important due to the increasing scarcity of raw materials, pollution targets, and carbon footprint targets set by governments. These factors include ecological and environmental aspects such as weather, climate, environmental offsets, and climate change which may especially affect industries such as tourism, farming, agriculture, and insurance. Furthermore, growing awareness of the potential impacts of climate change is affecting how companies operate and the products they offer. This has led to many companies getting more and more involved in practices such as corporate social responsibility (CSR) and sustainability.

\section{Legal Factors}

Although these factors may have some overlap with the political factors, they include more specific laws such as discrimination laws, antitrust laws, employment laws, consumer protection laws, copyright and patent laws, and health and safety laws. Companies need to know what is and what is not legal to trade successfully and ethically. If an organization trades globally this becomes especially tricky since each country has its own set of rules and regulations. Besides, you want to be 
aware of any potential changes in legislation and the impact it may have on your business in the future. Recommended is to have a legal advisor or attorney to help you with these kinds of things.

\section{Brief PESTEL Summary of Egypt}

Egypt is a transcontinental country spanning the northeast corner of Africa and southwest corner of Asia, via a land bridge formed by the Sinai Peninsula. Most of its territory of 390,000 square miles lies within the Nile Valley of North Africa and is bordered by the Mediterranean Sea to the north, the Gaza Strip and Palestine to the northeast, the Gulf of Aqaba to the east, the Red Sea to the east and south, Sudan to the south and Libya to the west.

Travel and tourism, transport, ICT, insurance \& finance, petroleum crude oil, machinery, agriculture, gold, electrical goods, electronics, and textiles are major industries of Egypt. In 2017, the Agriculture industry contributed 11.7\% to the GDP of Egypt. Manufacturing had a share of $34.3 \%$ while the services industry had a share of 54\% of GDP in 2017.

In 2018, Services industry exports were valued at USD 23.6 billion for Egypt. Electronics export accounted for USD 1.82 billion, machinery for USD 349 million, vehicles for USD 131 million, chemicals for USD 5.72 billion, metals for USD 2.56 billion, minerals for USD 9.33 billion, stones for USD 2.71 billion, textiles for USD 3.64 billion, and agriculture for USD 5.66 billion in $2018^{1}$.

Egypt Hotels Market Analytics to 2023: Rooms and Revenue Analytics report is published on May 11, 2020, and has 69 pages in it. This market research report provides information about Hotels \& Lodging, Food Service \& Hospitality, Country Overview, and Food \& Beverages industry. It covers Egypt market data and forecasts.

Egypt had an estimated population of 90.2 million in the year 2016 and is expected to reach 103.386 million by 2022. Egypt's unemployment rate was $12.571 \%$ of the total labor force in the same year. Egypt's real gross domestic product (GDP) was around EGP 1917.20 billion in 2016 whereas the nominal GDP was EGP 2708.30 billion. This resulted in a GDP deflator of 141.263. Per capita GDP was estimated at USD 3684.57 whereas purchasing power parity (PPP) based per capita GDP was estimated to be at USD 12553.94. In 2016, the Egyptian government's revenue was EGP 564.843 billion whereas the expenditure was EGP 890.143 billion. This resulted in the Egyptian government's net lending/borrowing negative at EGP 325.3 billion in 2016 indicating that enough financial resources were not made available by the government to boost economic growth. The current account balance for Egypt was estimated to be negative at USD 18.659 billion for the year 2016 and is expected to decrease at a CAGR of 53.17\%. Scope of Egypt - PESTEL Analysis Report.

In 2020 Egypt is estimated to have a population of 101.493 million and is expected to reach 112.244 million by 2024 , growing at a CAGR of $2.48 \%$.

\footnotetext{
${ }^{\mathrm{l}}$ https://www.marketresearchreports.com/countries/egypt. [Accessed 2 September 2020]
} 
Egypt's real gross domestic product (GDP) was EGP 2221.457 billion in 2019 and due to the COVID-19 outbreak, it is estimated to grow by $1.952 \%$ to be around EGP 2264.82 billion in 2020.

Egypt's unemployment rate was $8.612 \%$ of the total labor force in 2019 . Due to the slowdown in global economic activity due to the COVID-19 pandemic the unemployment is expected to increase by $16.34 \%$ and reach $10.294 \%$ in 2020 .

Egypt's per capita GDP was estimated at USD 3,019.72 whereas purchasing power parity (PPP) based per capita GDP is estimated to be at USD 14,028.03 for the year 2019.

In 2019, the Egyptian government's revenue was estimated to be EGP 1,083.46 billion whereas the expenditure is estimated to be EGP 1,543.26 billion. This resulted in the Egyptian government's net lending/borrowing negative at EGP 459.808 billion in 2019 indicating that not enough financial resources were made available by the government to boost economic growth.

The current account balance for Egypt was estimated to be negative at USD 7.119 billion for the year 2019 and is expected to further increase at a CAGR of $9.91 \%$ and reach USD - 4.223 billion by 2024 . This negative current account balance indicates that Egypt will remain a net borrower from the rest of the world till 2024.

In the World Bank's ease of doing business ranking, Egypt was ranked 114 out of 190 countries in 2019. Egypt's ease of doing business ranking has improved from the $120^{\text {th }}$ position in $2018^{2}$.

Aswan is a city in the south of Egypt, and is the capital of the Aswan Governorate. Aswan is a busy market and tourist center located just north of the Aswan Dam on the east bank of the Nile at the first cataract. The modern city has expanded and includes the formerly separate community on the island of Elephantine. Aswan is a large tourist city where a current population is $1,568,000$ (Egypt Statistics 2018).

Aswan is a Nubian city in the south of Egypt located on the east bank of the Nile river connected to Cairo with train stations, railways, and domestic flights; it is a population of almost about 900,000, The city of Aswan is about 85 meters above sea level, it is $879 \mathrm{~km}$ from Cairo, and its area about $34,608 \mathrm{~km}^{2}$.

The city also is known as the land of gold because it was like a huge necropolis for the pharaohs and their treasures for thousands of years. The originals of Aswan are the Nubian representing $30 \%$ of the citizens and they speak their Nubian language the rest are Arabs who came after the Islamic invasion speaking the Arabic language.

Aswan is characterized by its warm climate and rare plant islands, also there are rock Nile islands around the city extended from the high dam to the north of Edfu, some people of the Nubian villages and islands counts on farming and handmade items as a source of living and some already took place in governmental jobs, not only the main city of Aswan that has full services but also, the surrounding islands provided by hospitals, schools, and transportations, some of the islands are uninhabited because it is considered to be an archaeological area like the crocodile

\footnotetext{
${ }^{2}$ https://www.marketresearchrepor ts.org/countries/Egypt. [Accessed 2 September 2020]
} 
island and elephantine island which was a region linking the South and the North in the trade between Egypt and the rest of Africa. Aswan also is considered a huge economical source for the country's economy.

\title{
Private Dwellings Vacation Rentals in Aswan Governorate, Egypt
}

\author{
Elephantine - Taharka \\ The mango guest house (Syaha house) \\ Farm House \\ The Mango Guesthouse \\ Guesthouse Bet el Kerem Aswan Egypt \\ Nubian Lotus \\ Farm House 1 \\ Otasho Nile View House \\ Farm House $2^{3}$
}

\section{Aswan Attractions}

Aswan is full of ancient pharaonic civilization and many touristic destinations including pharaonic, Islamic, and Nubian monuments.

Many tourist activities can be practiced in Aswan. Some areas on the banks of the Nile in Aswan is suitable for swimming, others for sailing boats also, as well as travel to visit the islands of plants, museums, and temples on the islands of the middle of the river, such as ${ }^{4}$ :

- The Temple of Philae

- Elephantine island

- The Upper Dam

- The Aswan reservoir

- The Tabiya Mosque

- The Nile Museum

- The Princess Ferial Park

- The West Suhail area

- The Nile Islands

- kom Ombo temple

- The twin temple of Abu Simbel

\footnotetext{
${ }^{3}$ https://trip101.com/article/Airbnbs-in-aswan-governorate-egypt.

${ }^{4}$ https://www.traveltoegypt.net/discover-egypt/aswan-attractions/aswan-Information.
} 


\section{El-Wahat el-Bahariya or el-Bahariya}

Al-Wāhāat al-Bahrīya, "the Northern Oases"; Diwah Ēmbemdje, "Oasis of Bemdje", from Egyptian dsds is depression and oasis in the Western Desert of Egypt. It is approximately $370 \mathrm{~km}$ away from Cairo. The roughly oval valley extends from northeast to southwest, has a length of $94 \mathrm{~km}$, a maximum width of $42 \mathrm{~km}$ and covers an area of about $2000 \mathrm{~km}^{2}$.

The valley is surrounded by mountains and has numerous springs. Located in Giza Governorate, the main economic sectors are agriculture, iron ore mining, and tourism. The main agricultural products are guavas, mangos, dates, and olives.

Bahariya consists of many villages, of which El Bawiti is the largest and the administrative center. Qasr is el-Bawiti's neighboring/twin village. To the east, about ten kilometers away are the villages of Mandishah and el-Zabu. A smaller village called el-'Aguz lies between El Bawiti and Mandishah. Harrah, the easternmost village, is a few kilometers east of Mandishah and el-Zabu. El Hayz, also called El-Hayez, is the southernmost village, but it may not always be considered as part of Bahariya because it is so far from the rest of the villages, about fifty kilometers south of El Bawiti. There is an oasis at El-Hayez, where mummies have been found on which genetic studies have been conducted (Kujanová et al. 2009).

\section{Private Dwellings Vacation Rentals in Wahat Governorate, Egypt}

Ahmed Safari Camp white desert trips Bahariya Oasis

Desert Rose Eco Lodge, Hostel in the Oasis

New Elysium

Badry's Sahara Camp

Ahmed Safari Camp and hotel

Badry's Sahara Camp2

Campsite in Bahariya Oasis

Hany safari

Black and white desert safari

Cave in Mandishah ${ }^{5}$

\section{Wahat Attractions}

- White desert

- Sahara Souda - Black Desert

- The Crystal Mountain

- The Museum of Golden Mummies

- Gebel Magharafa

\footnotetext{
${ }^{5}$ https://www.Airbnb.co.in/s/El-Wahat/homes?refinement_paths\%5B $\% 5 \mathrm{D}=\% 2$ Fhomes\&source=str uctured_search_input_header\&search_type $=$ search_query\&tab_id=home_tab\&query=\%20Baharia $\% 2 \mathrm{C} \% 20$ egypt.
} 
- Lake Almarun

- Bawiti and Qasr

- Bannentui and DJED-ANKH-AMUN-IUF (ZED-AMUN)

- Gebel Al Ingleez

- Bir Sigam

- Valley of Agabat

As the background shows, the two destinations investigated enjoy plenty of attractions that are unique in nature and type; natural attractions that are not available anywhere else in the world. The review also revealed that PSTEL analysis of Egypt despite suffering some weaknesses, still permits and encourages the tourism industry and paves the way for the introduction of new applications like Airbnb in some Egyptian destinations with unique attractions like Aswan and Wahat Bahareya. It is worth mentioning that a few shelters are already offered in these two destinations for rent online. This might lead to the conclusion of the suitability of those two destinations for the application of Airbnb.

\section{Methodology}

A questionnaire form was developed, piloted, and corrected for reliability and validity. Alpha Cronbach test was applied. The reliability value calculated was 0.87 and validity 0.89 . This form was distributed on survey monkey for guests who previously visited designated areas (Aswan and Wahat) and stayed there. The questionnaire was administered during the period from March to August 2020. The same form was used for 109 tenants from Aswan and 118 from Wahat. Data collected were analyzed using SPSS version 20. t.test, f.test, and ANOVA tests were used to detect variances among groups that are investigated social and demographic elements of the PESTEL model. 


\section{Results and Discussion}

Table 1. Guests Responses to Social Adequacy of Destinations Investigated towards Airbnb Listings

\begin{tabular}{|c|c|c|c|c|c|c|c|c|c|c|c|c|c|}
\hline & \multicolumn{2}{|c|}{ Strongly disagree } & \multicolumn{2}{|c|}{ Disagree } & \multicolumn{2}{|c|}{$\begin{array}{c}\text { Neither agrees or } \\
\text { disagree }\end{array}$} & \multicolumn{2}{|c|}{ Agree } & \multicolumn{2}{|c|}{ Strongly agree } & \multirow[t]{2}{*}{ Total } & \multirow[t]{2}{*}{ Weight Average } & \multirow[t]{2}{*}{ Rank } \\
\hline & $\%$ & F & $\%$ & $\mathrm{~F}$ & $\%$ & $\mathrm{~F}$ & $\%$ & $\mathrm{~F}$ & $\%$ & F & & & \\
\hline $\begin{array}{l}\text { Population size and growth rate } \\
\text { fits. }\end{array}$ & 73.25 & 293 & 22.5 & 90 & 1.50 & 6 & 1.75 & 7 & 1.00 & 4 & 400 & 1.35 & 8 \\
\hline Wealth distribution fits. & 0.00 & 0 & 0.25 & 1 & 4.25 & 17 & 35.0 & 140 & 60.5 & 242 & 400 & 4.56 & 4 \\
\hline Social classes fit. & 0.00 & 0 & 0.50 & 2 & 4.25 & 17 & 33.2 & 133 & 62.0 & 248 & 400 & 4.57 & 3 \\
\hline Lifestyles fit. & 0.25 & 1 & 0.00 & 0 & 4.00 & 16 & 33.7 & 135 & 62.0 & 248 & 400 & 4.57 & 3 \\
\hline Health consciousness fits. & 72.50 & 290 & 24.25 & 97 & 1.00 & 4 & 1.50 & 6 & 0.75 & 3 & 400 & 1.34 & 9 \\
\hline $\begin{array}{l}\text { Attitude towards government } \\
\text { fits. }\end{array}$ & 0.50 & 2 & 0.25 & 1 & 4.25 & 17 & 36.25 & 145 & 58.75 & 235 & 400 & 4.53 & 5 \\
\hline Attitude towards work fits. & 0.00 & 0 & 0.25 & 1 & 3.25 & 13 & 36.25 & 145 & 60.25 & 241 & 400 & 4.57 & 3 \\
\hline Ethical concerns fit. & 72.00 & 288 & 21.75 & 87 & 2.25 & 9 & 2.25 & 9 & 1.75 & 7 & 400 & 1.4 & 7 \\
\hline Cultural norms and values fit. & 0.00 & 0 & 0.00 & 0 & 3.75 & 15 & 34.25 & 137 & 62.00 & 248 & 400 & 4.58 & 2 \\
\hline Education level fits. & 0.25 & 1 & 0.25 & 1 & 4.26 & 17 & 36.84 & 147 & 58.40 & 233 & 399 & 4.53 & 5 \\
\hline Crime levels fit. & 0.25 & 1 & 0.75 & 3 & 4.00 & 16 & 34.25 & 137 & 60.75 & 243 & 400 & 4.55 & 4 \\
\hline $\begin{array}{l}\text { Attitudes towards leisure time } \\
\text { fit. }\end{array}$ & 0.00 & 0 & 0.00 & 0 & 3.50 & 14 & 35.00 & 140 & 61.50 & 246 & 400 & 4.58 & 2 \\
\hline $\begin{array}{l}\text { Attitudes towards product } \\
\text { quality fit. }\end{array}$ & 0.00 & 0 & 0.00 & 0 & 4.25 & 17 & 34.75 & 139 & 61.00 & 244 & 400 & 4.57 & 3 \\
\hline $\begin{array}{l}\text { Attitudes towards customer } \\
\text { service fit. }\end{array}$ & 0.00 & 0 & 0.00 & 0 & 5.75 & 23 & 34.00 & 136 & 60.25 & 241 & 400 & 4.55 & 4 \\
\hline Discrimination laws fit. & 0.00 & 0 & 0.75 & 3 & 3.75 & 15 & 30.75 & 123 & 64.7 & 259 & 400 & 4.60 & 1 \\
\hline Antitrust laws fit. & 71.50 & 286 & 23.25 & 93 & 1.50 & 6 & 1.75 & 7 & 2.00 & 8 & 400 & 1.4 & 7 \\
\hline Consumer protection laws fit. & 0.25 & 1 & 0.50 & 2 & 3.75 & 15 & 38.50 & 154 & 57.00 & 228 & 400 & 4.51 & 6 \\
\hline Health and safety laws fit. & 0.25 & 1 & 0.00 & 0 & 4.25 & 17 & 36.00 & 144 & 59.50 & 238 & 400 & 4.55 & 4 \\
\hline Data protection laws fit. & 0.50 & 2 & 0.25 & 1 & 5.25 & 21 & 35.50 & 142 & 58.50 & 234 & 400 & 4.51 & 6 \\
\hline & & & & & & & & & & & & 400 & \\
\hline
\end{tabular}


Table 1 shows most social elements fit for Airbnb application as seen by guests and most elements weighted average revolved around 4.60 to 4.51 with very little dispersion around their mean $(\mathrm{m}=4.55)$. However, four elements namely, population size and growth rate, health consciousness of residents, ethical concerns of residents, and antitrust laws distorted the data. The calculated mean for these four elements is $(\mathrm{m}=1.37)$. This later mean is far lower than the rest of the elements investigated. This means that guests see the context of these elements as un-fit for the application of Airbnb in the investigated destinations. To further explore whether these elements are common in both destinations Anova test was carried out as displayed in the Table 2.

Table 2. ANOVA Test for Symmetry between Aswan and Wahat Tourist Destinations

\begin{tabular}{|l|c|c|c|c|c|c|}
\hline \multirow{2}{*}{} & \multicolumn{7}{|c|}{ Summary of Data } \\
\cline { 2 - 8 } & 1 & 2 & 3 & 4 & 5 & Total \\
\hline $\mathbf{N}$ & 22 & 22 & & & & 44 \\
\hline$\sum \mathbf{X}$ & 68.53 & 74.53 & & & & 143.06 \\
\hline Mean & 3.115 & 3.3877 & & & & 3.251 \\
\hline$\sum \mathbf{X}^{2}$ & 229.219 & 270.5481 & & & & 0.8974 \\
\hline Std.Dev. & 0.866 & 0.9274 & & & & \\
\hline & & Result Details & & \\
\hline Source & $\mathbf{S S}$ & df & MS & & & \\
\hline $\begin{array}{l}\text { Between- } \\
\text { treatments }\end{array}$ & 0.8182 & 1 & 0.8182 & $F=1.01641$ & & \\
\hline $\begin{array}{l}\text { Within- } \\
\text { treatments }\end{array}$ & 33.8087 & 42 & 0.805 & & & \\
\hline Total & 34.6269 & 43 & & & & \\
\hline
\end{tabular}

The $\mathrm{f}$-ratio value is 1.01641 . The $\mathrm{p}$-value is 0.319145 . The result is not significant at $\mathrm{p}<0.05$.

The abovementioned Anova test results indicate there are significant differences among Aswan and Wahat $(\mathrm{p}=0.319145)$ about adequacy to apply Airbnb applications and the use of private dwellings of residents for that purpose.

To further explore the case, tenants' viewpoints in both destinations were checked against those of guests. The Anova test was used for that purpose. Table 3 shows the viewpoints of tenants in Aswan. These viewpoints are based on their responses to the questionnaire forms conducted face to face with them during the same period of study as previously mentioned. 
Table 3. Aswan Tenants on Social Elements Fit for Airbnb Application

\begin{tabular}{|c|c|c|c|c|c|c|c|c|c|c|c|c|c|}
\hline & \multicolumn{2}{|c|}{ Strongly disagree } & \multicolumn{2}{|c|}{ Disagree } & \multicolumn{2}{|c|}{ Neither agree nor disagree } & \multicolumn{2}{|c|}{ Agree } & \multicolumn{2}{|c|}{ Strongly agree } & \multirow[t]{2}{*}{ Total } & \multirow[t]{2}{*}{ Weight Average } & \multirow[t]{2}{*}{ Rank } \\
\hline & $\%$ & $\mathrm{~F}$ & $\%$ & $\mathrm{~F}$ & $\%$ & $\mathrm{~F}$ & $\%$ & $\mathrm{~F}$ & $\%$ & $\mathrm{~F}$ & & & \\
\hline Population size and growth rate fits. & 58.72 & 64 & 33.03 & 36 & 7.34 & 8 & 0.92 & 1 & 0.00 & 0 & 109 & 1.5 & 14 \\
\hline Age distribution fits. & 1.83 & 2 & 0.92 & 1 & 50.46 & 55 & 30.28 & 33 & 16.51 & 18 & 109 & 3.59 & 3 \\
\hline Wealth distribution fits. & 1.83 & 2 & 0.92 & 1 & 49.54 & 54 & 29.36 & 32 & 18.35 & 20 & 109 & 3.61 & 1 \\
\hline Social classes fit. & 1.83 & 2 & 0.0 & 0 & 51.38 & 56 & 34.86 & 38 & 11.93 & 13 & 109 & 3.55 & 7 \\
\hline Family size and structure fit. & 1.83 & 2 & 0.92 & 1 & 49.54 & 54 & 31.19 & 34 & 16.51 & 18 & 109 & 3.6 & 2 \\
\hline Lifestyles fit. & 1.83 & 2 & 0.00 & 0 & 51.38 & 56 & 31.19 & 34 & 15.60 & 17 & 109 & 3.59 & 3 \\
\hline Health consciousness fits. & 51.38 & 56 & 40.37 & 44 & 7.34 & 8 & 0.92 & 1 & 0.00 & 0 & 109 & 1.58 & 11 \\
\hline Attitude towards government fits. & 1.85 & 2 & 1.85 & 2 & 49.07 & 53 & 36.11 & 39 & 11.11 & 12 & 108 & 3.53 & 8 \\
\hline Attitude towards work fits. & 1.83 & 2 & 1.83 & 2 & 50.46 & 55 & 27.52 & 30 & 18.35 & 20 & 109 & 3.59 & 3 \\
\hline § Buying habits fit. & 1.83 & 2 & 0.92 & 1 & 52.29 & 57 & 33.03 & 36 & 11.93 & 13 & 109 & 3.52 & 9 \\
\hline Ethical concerns fit. & 54.13 & 59 & 38.53 & 42 & 5.50 & 6 & 1.83 & 2 & 0.00 & 0 & 109 & 1.55 & 13 \\
\hline Cultural norms and values fit. & 1.83 & 2 & 0.92 & 1 & 51.38 & 56 & 33.03 & 36 & 12.84 & 14 & 109 & 3.54 & 6 \\
\hline Sex roles and distribution fit. & 1.83 & 2 & 0.92 & 1 & 52.29 & 57 & 24.77 & 27 & 20.18 & 22 & 109 & 3.61 & 1 \\
\hline Religion and beliefs fit. & 1.83 & 2 & 0.92 & 1 & 53.21 & 58 & 31.19 & 34 & 12.84 & 14 & 109 & 3.52 & 9 \\
\hline Racial equality fits. & 53.21 & 58 & 40.37 & 44 & 4.59 & 5 & 0.92 & 1 & 0.92 & 1 & 109 & 1.56 & 12 \\
\hline Education level fits. & 1.83 & 2 & 0.92 & 1 & 49.5 & 54 & 35.78 & 39 & 11.93 & 13 & 109 & 3.55 & 5 \\
\hline Minorities fit. & 49.54 & 54 & 43.12 & 47 & 6.42 & 7 & 0.92 & 1 & 0.00 & 0 & 109 & 1.59 & 10 \\
\hline Crime levels fit. & 1.83 & 2 & 0.92 & 1 & 48.62 & 53 & 35.78 & 39 & 12.84 & 14 & 109 & 3.57 & 5 \\
\hline Attitudes towards leisure time fit. & 1.83 & 2 & 0.92 & 1 & 49.54 & 54 & 32.11 & 35 & 15.60 & 17 & 109 & 3.59 & 3 \\
\hline Attitudes towards product quality fit. & 1.83 & 2 & 0.92 & 1 & 47.71 & 52 & 33.03 & 36 & 16.51 & 18 & 109 & 3.61 & 1 \\
\hline Attitudes towards customer service fit. & 1.83 & 2 & 0.92 & 1 & 50.46 & 55 & 29.36 & 32 & 17.43 & 19 & 109 & 3.6 & 2 \\
\hline Attitudes towards foreign people fit. & 1.83 & 2 & 0.00 & 0 & 49.54 & 54 & 35.78 & 39 & 12.84 & 14 & 109 & 3.58 & 4 \\
\hline & & & & & & & & & & & & 109 & \\
\hline
\end{tabular}


Table 3 displays how Aswan tenants see social and demographic elements in their destination fit for the Airbnb application. Those dwellings owners expressed that most elements fit. Major fitting elements grouped had a mean of $(\mathrm{m}=3.56)$ where all these elements had little dispersion around this mean. However, the elements of population size, health consciousness, ethical concerns, minorities distorted the data since this group's arithmetic mean is much less than the former where $(m=1.54)$. Issues like minorities and discrimination may have arisen due to the historical Nuba residents' problem that the Egyptian Government is working on. The population problem is a temporary issue since many residents left Aswan to other governorates due to high fluctuations in Tourism demand for this destination for the past decade due to many political, economic, and endemic reasons. Health consciousness elements are also temporary since it is impacted by depression due to lack of tourism demand and absence of health insurance plans among most Aswan residents who mainly work in the private sector which traditionally does not support or supports limitedly health insurance plans. The ethical element is the main issue of concern here since it points out to lack of awareness. This awareness is the outcome of the Ministry of Tourism "MoT" and the Egyptian Tourism Federation "E.T.F" awareness plans that are absent for the past two decades.

Table 4. ANOVA Test on Differences among Guests and Tenants in Aswan towards Airbnb Application

\begin{tabular}{|c|c|c|c|c|c|c|}
\hline \multicolumn{7}{|c|}{ Summary of Data } \\
\hline & \multicolumn{6}{|c|}{ Treatments } \\
\hline & 1 & 2 & 3 & 4 & 5 & Total \\
\hline $\mathbf{N}$ & 22 & 19 & & & & 41 \\
\hline$\sum \mathbf{X}$ & 68.53 & 73.82 & & & & 142.35 \\
\hline Mean & 3.115 & 3.8853 & & & & 3.472 \\
\hline$\sum \mathbf{X}^{2}$ & 229.219 & 318.8136 & & & & 548.033 \\
\hline Std.Dev. & 0.866 & 1.3334 & & & & 1.1597 \\
\hline \multicolumn{7}{|c|}{ Result Details } \\
\hline Source & $S S$ & $d f$ & $M S$ & & & \\
\hline $\begin{array}{l}\text { Between- } \\
\text { treatments }\end{array}$ & 6.0488 & 1 & 6.0488 & $\begin{array}{c}F= \\
4.94025\end{array}$ & & \\
\hline Within-treatments & 47.7514 & 39 & 1.2244 & & & \\
\hline Total & 53.8002 & 40 & & & & \\
\hline
\end{tabular}

The f-ratio value is 4.94025 . The $p$-value is .032106 . The result is significant at $p<0.05$.

Significant differences arise between guests from one side and tenants of Aswan private dwellings towards how social and demographic elements fir for use of these dwellings as Airbnb listings since $\mathrm{p}$-value $(\mathrm{p}=0.32106)$ as in Table 4 . Tenants were the reason behind this difference since they exceeded guests in criticizing elements (included minorities issues) in their judgment. Since Aswan is an old well known Egyptian destination that was renowned centuries ago, this places a responsibility on the government of Egypt to speed up the resolution of Nuba and minorities issue to make the way clear for tenants of private dwellings to willingly use them under the umbrella of Airbnb, the step that can boost inbound tourism to the destination specifically and the state of Egypt on the whole. 
Table 5. ANOVA Test on Differences among Guests and Tenants in Wahat towards Airbnb Application

\begin{tabular}{|c|c|c|c|c|c|c|c|c|c|c|c|c|c|}
\hline & \multicolumn{2}{|c|}{ Strongly disagree } & \multicolumn{2}{|c|}{ Disagree } & \multicolumn{2}{|c|}{ Neither agree nor disagree } & \multicolumn{2}{|c|}{ Agree } & \multicolumn{2}{|c|}{ Strongly agree } & \multirow[t]{2}{*}{ Total } & \multirow[t]{2}{*}{ Weighted Average } & \multirow[t]{2}{*}{ Rank } \\
\hline & $\%$ & $\mathrm{~F}$ & $\%$ & $\mathrm{~F}$ & $\%$ & $\mathrm{~F}$ & $\%$ & $\mathrm{~F}$ & $\%$ & $\mathrm{~F}$ & & & \\
\hline Population size and growth rate fits. & 38.14 & 45 & 58.47 & 69 & 2.54 & 3 & 0.85 & 1 & 0.00 & 0 & 118 & 1.66 & 11 \\
\hline Age distribution fits. & 2.54 & 3 & 13.56 & 16 & 8.47 & 10 & 56.78 & 67 & 18.64 & 22 & 118 & 3.75 & 9 \\
\hline Wealth distribution fits. & 1.71 & 2 & 8.55 & 10 & 11.97 & 14 & 53.85 & 63 & 23.93 & 28 & 117 & 3.9 & 4 \\
\hline Social classes fit. & 0.85 & 1 & 10.17 & 12 & 11.86 & 14 & 55.93 & 66 & 21.19 & 25 & 118 & 3.86 & 6 \\
\hline Family size and structure fit. & 0.85 & 1 & 10.17 & 12 & 12.71 & 15 & 53.39 & 63 & 22.88 & 27 & 118 & 3.87 & 5 \\
\hline Lifestyles fit. & 0.00 & 0 & 14.41 & 17 & 14.41 & 17 & 43.22 & 51 & 27.97 & 33 & 118 & 3.85 & 7 \\
\hline Health consciousness fits. & 41.53 & 49 & 51.69 & 61 & 0.00 & 0 & 5.08 & 6 & 1.69 & 2 & 118 & 1.74 & 10 \\
\hline Attitude towards government fits. & 0.00 & 0 & 11.02 & 13 & 11.02 & 13 & 57.63 & 68 & 20.34 & 24 & 118 & 3.87 & 5 \\
\hline Attitude towards work fits. & 0.85 & 1 & 11.0 & 13 & 9.32 & 11 & 55.08 & 65 & 23.73 & 28 & 118 & 3.9 & 4 \\
\hline Buying habits fit. & 1.69 & 2 & 13.56 & 16 & 10.17 & 12 & 54.24 & 64 & 20.34 & 24 & 118 & 3.78 & 8 \\
\hline Ethical concerns fit. & 46.61 & 55 & 45.76 & 54 & 4.24 & 5 & 2.54 & 3 & 0.85 & 1 & 118 & 1.65 & 12 \\
\hline Cultural norms and values fit. & 1.69 & 2 & 11.02 & 13 & 8.47 & 10 & 56.78 & 67 & 22.03 & 26 & 118 & 3.86 & 6 \\
\hline Sex roles and distribution fit. & 0.85 & 1 & 10.17 & 12 & 6.78 & 8 & 60.17 & 71 & 22.03 & 26 & 118 & 3.92 & 3 \\
\hline Religion and beliefs fit. & 0.85 & 1 & 11.86 & 14 & 10.17 & 12 & 49.15 & 58 & 27.97 & 33 & 118 & 3.92 & 3 \\
\hline Racial equality fits. & 44.07 & 52 & 43.22 & 51 & 5.93 & 7 & 5.08 & 6 & 1.69 & 2 & 118 & 3.87 & 5 \\
\hline Education level fits. & 1.69 & 2 & 9.32 & 11 & 7.63 & 9 & 60.17 & 71 & 21.19 & 25 & 118 & 3.9 & 4 \\
\hline Minorities fit. & 38.98 & 46 & 52.54 & 62 & 2.54 & 3 & 3.39 & 4 & 2.54 & 3 & 118 & 3.87 & 5 \\
\hline Crime levels fit. & 0.00 & 0 & 11.86 & 14 & 6.78 & 8 & 55.93 & 66 & 25.42 & 30 & 118 & 3.95 & 2 \\
\hline Attitudes towards leisure time fit. & 0.85 & 1 & 11.86 & 14 & 11.02 & 13 & 54.24 & 64 & 22.03 & 26 & 118 & 3.85 & 7 \\
\hline Attitudes towards product quality fit. & 0.85 & 1 & 13.56 & 16 & 5.08 & 6 & 48.31 & 57 & 32.20 & 38 & 118 & 3.97 & 1 \\
\hline Attitudes towards customer service fit. & 0.85 & 1 & 12.71 & 15 & 9.32 & 11 & 53.39 & 63 & 23.73 & 28 & 118 & 3.86 & 6 \\
\hline Attitudes towards foreign people fit. & 1.69 & 2 & 10.17 & 12 & 8.47 & 10 & 53.39 & 63 & 26.27 & 31 & 118 & 3.92 & 3 \\
\hline & & & & & & & & & & & & 118 & \\
\hline
\end{tabular}


Tenants of private dwellings in Wahat see that most social and demographic elements of their destination make it possible for their dwellings to be used as rent listings under the Airbnb umbrella. The mean of this group of elements is $(\mathrm{m}=3.86)$ with little dispersion around this mean for this group of elements. Population, health consciousness, and ethical concerns had a different mean $(\mathrm{m}=1.37)$ as seen in Table 5. The population is limited in this governorate because little economic activities take place there. The Health consciousness element is also since most residents work for the private sector as in the case of Aswan. Ethical concerns refer to the same previous findings, i.e., lack of awareness campaigns provided by "MoT" and "E.T.F". To further explore the case of Wahat, the Anova test was carried out. Table 6 displays the results of this test.

Table 6. ANOVA Test on Differences among Guests and Tenants in Wahat towards Airbnb Application

\begin{tabular}{|c|c|c|c|c|c|c|}
\hline \multicolumn{7}{|c|}{ Summary of Data } \\
\hline \multicolumn{7}{|c|}{ Treatments } \\
\hline & 1 & 2 & 3 & 4 & 5 & Total \\
\hline $\mathbf{N}$ & 22 & 19 & & & & 41 \\
\hline$\sum \mathbf{X}$ & 74.53 & 73.82 & & & & 148.35 \\
\hline Mean & 3.3877 & 3.8853 & & & & 3.618 \\
\hline$\sum \mathbf{X}^{2}$ & 270.548 & 318.8136 & & & & 589.362 \\
\hline Std.Dev. & 0.9274 & 1.3334 & & & & 1.1466 \\
\hline \multicolumn{7}{|c|}{ Result Details } \\
\hline Source & $S S$ & $d f$ & $M S$ & & & \\
\hline $\begin{array}{l}\text { Between- } \\
\text { treatments }\end{array}$ & 2.5237 & 1 & 2.5237 & $\begin{array}{c}F= \\
1.96598\end{array}$ & & \\
\hline Within-treatments & 50.0643 & 39 & 1.2837 & & & \\
\hline Total & 52.588 & 40 & & & & \\
\hline
\end{tabular}

Table 6 indicates there are no significant differences between viewpoints of Wahat tenants and guests towards how social and demographic elements are adequate for the use of private dwellings as Airbnb rent listings. Both guests and tenants agreed that this is possible in Wahat. Both groups also agreed on the elements that may hider this, i.e., population, health consciousness, and ethical concerns.

\section{Conclusion}

Albeit the multiple pros and cons Airbnb remains a good platform that allows private dwellings owners to take part in the global tourism movement being available in 151 states around the world. As the largest sharing economy platform worldwide, Airbnb with 500 million visitors and more than 3 billion us dollars profit in 2020 can introduce a golden chance for many destinations around the world. In one place, namely Paris, more than 78,000 Airbnb listings are available there. Destinations like Aswan and Wahat in Egypt can get huge benefits from such a platform. Tenants of private dwellings in these two Egyptian destinations 
already rent them online to tourists. This is taking place away from the "MoT" or "E.T.F" umbrella. Moreover, this is also taking place apart from Airbnb platform albeit being online. PESTEL model analysis was instituted to check the readiness of these destinations to adopt the Airbnb platform. In the case of the state on the whole, all dimensions proved to fit, except for the social one in Aswan, despite being an old renowned tourist destination however, it proved to be less ready than Wahat to adopt the Airbnb platform. Surprisingly, this is because of very local, social and demographic issues that relate to what Nubian residents believe, is a sort of "discrimination and racial disputes". Other factors included population, health consciousness, and ethical issues which are temporary in nature due to the current situation of damped tourism demand. This means that social and demographic factors did hinder the use of the Airbnb platform in this destination which can lead to a boom in bed capacity and visitors at the same time for their authenticity, price and, novelty. It also proves the capacity of such factors to hinder the progress and development of tourism to destinations it is a government mandate to clear up the resolution of the Nubian dispute (that Nubians look at as a discriminative act) to pave the way for Airbnb adoption. This sheds the light on the fact that minor social and demographic issues on the micro-level can hinder or even block down tourism-related activities and the adoption of shared economy platforms. Social and demographic issues might constitute the only nonpolitical dimension in the PESTEL model that can confine the readiness of the destination for progress since other dimensions are unified across the country, but not this one. Using a macro-vision the same concept applies to government investments in developing tourism destinations albeit the existence of such issues could mean the waste of governmental investments in such destinations.

\section{References}

Aaker JL (2011) Dimensions of brand personality. Journal of Marketing Research 34(3): $347-356$.

Adner R (2002) When are technologies disruptive? A demand-based view of the emergence of competition. Strategic Management Journal 23(8): 667-688.

Ahuvia A, Izberk-Bilgin E (2011) Limits of the McDonaldization thesis: Bayization and ascendant trends in post-industrial consumer culture. Consumption Markets \& Culture 14(4): 361-384.

Airbnb (2012) Airbnb hosts and guests have a major positive effect on city economies. Airbnb. Retrieved from: https://bit.ly/3aagPUd. [Accessed 11 February 2021]

Airbnb (2103) Airbnb economic impact. Retrieved from: https://blog.atairbnb.com/econo mic-impact-airbnb/. [Accessed 25 April 2017]

Airbnb (2014) Airbnb economic impact. The Airbnb Blog, Airbnb.

Airbnb (2015) Airbnb summer travel report Retrieved from: https://blog.atairbnb.com/wpcontent/uploads/2015/09/Airbnb-Summer-Travel-Report-1.pdf. [Accessed 28 April 2017]

Airbnb (2016) Fast facts. Retrieved from: https://press.atAirbnb.com/fast-facts/. [Accessed 18 April 2018]

Botsman R, Rogers R (2010) What's mine is yours: the rise of collaborative consumption. New York, NY: Harper Business. 
Bower JL, Christensen CM (1995) Disruptive technologies: catching the wave. Harvard Business Review Jan-Feb: 43-53.

Bradbury S (2014). Couch surfing trend spurs calls for taxes, regulations to even playing field with hotels. Times Free Press.

Buhr S (2014). Brian Chesky talks about just how different the hotel business is from Airbnb. TechCrunch.

Cadwalladr C (2013). Airbnb: the travel revolution in our spare rooms. The Guardian.

Capellaro C (2013). A bed \& breakfast on every block: as Airbnb home rentals multiply, Madison regulators get antsy. Isthmus.

Cha S, McCleary KW, Uysal M (1995) Travel motivations of Japanese overseas travelers: a factor-cluster segmentation approach. Journal of Travel Research 34(1): 33-39.

Chang J, Wall G, Chu STT (2006) Novelty seeking at aboriginal attractions. Annals of Tourism Research 33(3): 729-747.

Chase R (2015) Peers Inc: how people and platforms are inventing the collaborative economy and reinventing capitalism. New York, NY: Public Affairs.

Christensen CM (1997) The innovator's dilemma: when new technologies cause great firms to fail. Boston, MA: Harvard Business School Press.

Chu RK, Choi T (2000) An importance-performance analysis of hotel selection factors in the Hong Kong hotel industry: a comparison of business and leisure travelers. Tourism Management 21(4): 363-377.

Clampet J (2014). Airbnb in NYC: the real numbers behind the sharing story. Skift.

Cohen E (1972) Toward a sociology of international tourism. Social Research 39(1): 164182.

Coldwell W (2016). Airbnb: from home-sharing cool to the commercial giant. The Guardian.

Dolnicar S, Otter T (2003) Which hotel attributes matter? A review of previous and a framework for future research. In T Griffin, R Harris (eds.), Proceedings of the $9^{\text {th }}$ Annual Conference of the Asia Pacific Tourism Association (APTA), 176-188. Sydney, Australia: University of Technology Sydney.

Egypt Statistics (2018) Population of Egypt now. Central Agency for Public Mobilization and Statistics, Egypt Statistics.

Ennion J (2013). Airbnb: the new black. Stuff.

Ert E, Fleischer A, Magen N (2016) Trust and reputation in the sharing economy: the role of personal photos in Airbnb. Tourism Management 55(Aug): 62-73.

Gansky L (2010) The mesh: why the future of business is sharing. New York, NY: Penguin.

Gilmore JH, Pine BJ (2011) Differentiating hospitality operations via experiences: why selling services is not enough. The Cornell Hotel and Restaurant Administration Quarterly 43(3), 87-96.

Guttentag D (2015) Airbnb: disruptive innovation and the rise of an informal tourism accommodation sector. Current Issues in Tourism 18(12): 1192-1217.

Hamari J, Sjöklint M, Ukkonen A (2015) The sharing economy: why people participate in collaborative consumption. Journal of the Association for Information Science and Technology 67(9): 2047-2059.

Harwell D (2014) Tampa Bay's explosive vacation-rental growth sparks battles in neighborhoods. Tampa Bay Times.

Haywood J, Hoyt A, Wilson C, Hennis S, Alvarado C (2016). STR: Airbnb's impact minor on Manhattan hotels. Hotel News Now.

Hockenson L (2013) Airbnb is 20\% to 50\% cheaper than a hotel (unless you're in Vegas or Houston). Gigaom. 
Huurne M, Ronteltap A, Corten R, Buskens V (2017) Antecedents of trust in the sharing economy: a systematic review. Journal of Consumer Behavior 16(6): 485-498.

Jang SS, Feng R (2007) Temporal destination revisit intention: the effects of novelty seeking and satisfaction. Tourism Management 28(2): 580-590.

Khare A, Singh S, Khare A (2010) Innovativeness/novelty-seeking behavior as determinants of online shopping behavior among Indian youth. Journal of Internet Commerce 9(3-4): 164-185.

Kim SS, Prideaux B (2005) Marketing implications arising from a comparative study of international pleasure tourist motivations and other travel-related characteristics of visitors to Korea. Tourism Management 26(3): 347-357.

Kim K, Noh J, Jogaratnam G (2007) Multi-destination segmentation based on push and pull motives: pleasure trips of students at a US university. Journal of Travel \& Tourism Marketing 21(2-3): 19-32.

Kujanová M, Pereira L, Fernandes V, Pereira JB, Černý V (2009) Near eastern Neolithic genetic input in a small oasis of the Egyptian western desert. American Journal of Physical Anthropology 140(2): 336-346.

Lamb Z (2011) Rethinking authenticity in tourist experience: analyzing the motivations of travelers in person-to-person hospitality networks. Master Thesis. Chicago, IL: The University of Chicago.

Lancaster KJ (1966) A new approach to consumer theory. The Journal of Political Economy 74(2): 132-157.

Lee S, Kim DY (2018) The brand personality of Airbnb: application of user involvement and gender differences. Journal of Travel Tourism and Marketing 35(1): 32-45.

Lee G, O'Leary JT, Lee SH, Morrison A (2002) Comparison and contrast of push and pull motivational effects on trip behavior: an application of a multinomial logistic regression model. Tourism Analysis 7(2): 89-104.

Lee D, Hyun W, Ryu J, Lee WJ, Rhee W, Suh B (2015) An analysis of social features associated with room sales of Airbnb. In Companion of the $18^{\text {th }}$ ACM Conference Companion on Computer Supported Cooperative Work \& Social Computing, 219222. Vancouver, Canada.

Liang LJ, Choi HSC, Joppe M (2018) Understanding repurchase intention of Airbnb consumers: perceived authenticity, electronic word-of-mouth, and price sensitivity. Journal of Travel, Tourism, and Marketing 35(1): 75-89.

Lieber R (2015). Airbnb's lodging gets tested, yielding a mixed bag. The New York Times.

Moody M, Suess C, Lehto X (2017) The Accommodation Experiences cape: A Comparative Assessment of Hotels and Airbnb. International Journal of Contemporary Hospitality Management 29(9): 2377-2404.

Nowak B, Allen T, Rollo J, Lewis V, He L, Chen A et al. (2015) Global insight: whom will Airbnb hurt more - hotels or OTAs? Morgan Stanley Research.

O'Neill JW, Ouyang Y (2016) From air mattresses to unregulated business: an analysis of the other side of Airbnb. PennState.

Parigi P, Cook K (2015) Trust and relationships in the sharing economy. Contexts: Understanding People in Their Social Worlds 14(1): 18-19.

Perera R (2017) The PESTEL analysis. Nerdynaut.

Pilon M (2014). Airbnb, an alternative to hotels for New York Marathon runners, isn't welcome by all. The New York Times.

Popper B (2015) Airbnb's worst problems are confirmed by its data. The Verge.

PricewaterhouseCooper (2015) Consumer intelligence series: the sharing economy. Price waterhouseCooper.

Quinby D, Gasdia M (2014) Share this! Private accommodation \& the rise of the new-gen renter. Phocus wright. 
Rogers EM (2003) Diffusion of innovations. $5^{\text {th }}$ Edition. New York, NY: Free Press.

Rosenberg A (2014) The best reason to Airbnb while traveling abroad. Washington Post.

Schneiderman ET (2014) Airbnb in the city. New York, NY: Office of the New York State Attorney General.

Schoettle A (2015). Airbnb gets a foothold in Indianapolis. Indianapolis Business Journal.

Shead S (2015) Airbnb: Europe is the largest market but engineers will stay in San Francisco. Tech-world.

Sirakaya E, Uysal M, Yoshioka CF (2003) Segmenting the Japanese tour market to Turkey. Journal of Travel Research 41(3): 293-304.

Slee T (2013) Airbnb in New York: economical with the truth. Tom Slee.

Slee T (2014) The shape of Airbnb's business. Whimsey. Tom Slee.

Snepenger DJ (1987) Segmenting the vacation market by novelty-seeking role. Journal of Travel Research 26(2): 8-14.

So KKF, Oh H, Min S (2018) Motivations and constraints of Airbnb consumers: findings from a mixed-methods approach. Tourism Management 67(Aug) 224-236.

St. Louis R (2012) Barcelona. $8^{\text {th }}$ Edition. Oakland, CA: Lonely Planet.

Sun N, Liu D, Zhu A, Chen Y, Yuan Y (2019) Do Airbnb's super hosts deserve the badge? An empirical study from China. Asia Pacific Journal of Tourism Research 24(4): 296-313.

Taylor C (2012). Airbnb hits hockey stick growth: 10 Million nights booked, 200k active properties. TechCrunch.

Tussyadiah I (2015) An exploratory study on drivers and deterrents of collaborative consumption in travel. In I Tussyadiah, A Inversini (eds.), Information \& Communication Technologies in Tourism 2015, 817-830. Switzerland: Springer International Publishing.

Tussyadiah I, Pesonen J (2015) Impacts of peer-to-peer accommodation use on travel patterns. Journal of Travel Research (Oct).

Tussyadiah I, Zach FJ (2015) Hotels vs. peer-to-peer accommodation rentals: text analytics of consumer reviews in Portland, Oregon. Presented at the Travel and Tourism Research Association (TTRA) $46^{\text {th }}$ Annual International Conference, Portland, OR, and June 15-17, 2015.

Tussyadiah IP, Pesonen J (2018) Impacts of peer-to-peer accommodation use on travel patterns. Journal of Travel Research 55(8): 1022-1040.

Vaccaro A (2014) Boston mulling Airbnb regulations, won't fine hosts in meantime. Boston.com.

Weisleder M (201) Is Airbnb legal in Ontario? Toronto Star.

Williams C (2014) Airbnb aims to reshape the travel industry. The Telegraph.

Williams N, Berry O, Butler S, Carillet J-B, Christiani K, Clark G et al. (2015) France. $11^{\text {th }}$ Edition. Oakland, CA: Lonely Planet.

Wu J, Ma P, Xie KL (2017) in sharing economy we trust: the effects of host attributes on short-term rental purchases. International Journal of Contemporary Hospitality Management 29(11): 2962-2976.

Zhang Z, Chen RJC, Han LD, Yang L (2017) Key factors affecting the price of Airbnb listings: a geographically weighted approach. Sustainability 9(9): 1635. 